\title{
THE DEVELOPMENT OF CO-CURRICULAR INTERVENTIONS TO STRENGTHEN FEMALE ENGINEERING STUDENTS' SENSE OF SELF-EFFICACY AND TO IMPROVE THE RETENTION OF WOMEN IN TRADITIONALLY MALE-DOMINATED DISCIPLINES AND CAREERS
}

\author{
A. Lourens \\ Department of Industrial Engineering \\ Nelson Mandela Metropolitan University, South Africa \\ ann.lourens@nmmu.ac.za
}

\begin{abstract}
ABST RACT
Self-efficacy relates to positive outcomes for women studying and working in traditionally male-dominated fields such as engineering, science, and technology. Many women engineering students (WES) experience fear and insecurity about how they will be treated and perceived in this traditionally male-dominated field, either as a WES or as a working engineer. This study provides support for the development of co-curricular interventions to improve the self-efficacy of WES at a South African tertiary institution. The research design for this study is based on a phenomenological approach that uses a process of critical analysis of evaluation and feedback documents relating to the various co-curricular interventions and their perceived influence on selected WES's self-efficacy. Finally, as there has been no other South African research on WES and the sources of self-efficacy, this research is unique in the South African context.
\end{abstract}

\section{OPSOMMING}

Daar is ' $n$ verband tussen selfdoeltreffendheid en positiewe resultate vir vroue wat studeer en werk in tradisionele mansgedomineerde dissiplines, soos ingenieurswese. Daar is egter baie vroulike ingenieurswese studente wat vrese en onsekerhede ervaar oor hoe hulle behandel en waargeneem sal word in ' $n$ tradisionele, mansgedomineerde dissipline, hetsy as student of as werkende ingenieur. Hierdie navorsingstudie bied ondersteuning vir die ontwikkeling van mede-kurrikulêre ingrypings om die selfdoeltreffendheid van vroue studente in ingenieurswese aan ' $n$ Suid-Afrikaanse tersiêre instelling te verbeter. Die navorsing in hierdie studie is gebaseer op ' $n$ fenomenologiese benadering, en gebruik ' $n$ proses van kritiese ontleding van evaluering en terugvoer dokumente van verskillende mede-kurrikulêre ingrypings, en die invloed daarvan op geselekteerde vroue ingenieurstudente se selfdoeltreffendheid. Ten slotte, aangesien geen ander SuidAfrikaanse navorsing oor selfdoeltreffendheid en vroulike ingenieurswese studente gevind kon word nie, is hierdie studie uniek in die Suid-Afrikaanse konteks. 


\section{$1 \quad$ INTRODUCTION}

Du Toit and Roodt [1] reported a decline in the percentage of female engineering professionals participating in the South African labour market, from 16.21 per cent in 1996 to 10.51 per cent in 2005. The declining trend is a concern in light of the critical shortage of engineering skills, knowledge, and competencies in South Africa, and it highlights the under-representation of women in engineering. The percentage of women undertaking engineering studies in South Africa increased, however, from 9.4 per cent in 1996, to 20.2 per cent in 2005 [1]. This indicates that initiatives to attract female learners into engineering studies have been effective. In light of these trends, it would appear that the emphasis should not only be on the recruitment of women into engineering, but also on the retention of women in engineering. Since 1996, women represented only about 10 per cent of the engineering workforce, although they constituted about a fifth of the engineering student population [1].

One of the initiatives to improve the retention rates of women engineering students (WES) and practising female engineering professionals is the Women in Engineering Leadership Association (WELA). WELA was launched in South Africa in 2011 by the Nelson Mandela Metropolitan University's (NMMU) School of Engineering, together with the Chair in Engineering Development from the Manufacturing, Engineering and Related Services Sector Education and Training Authority (merSETA). WELA's goal is the academic, professional, and personal development of women in engineering, thereby helping to attract and retain women in the field of engineering. Further to this aim, several co-curricular interventions and activities were developed for WES who are members of WELA [2]. These interventions and activities were developed to incorporate the four sources of self-efficacy: mastery experiences, social persuasion, vicarious experiences, and physiological states [3]. Increased self-efficacy relates to positive outcomes for women studying and working in traditionally male-dominated fields, such as engineering, science, and technology [4]. Data collected over a two-year period from WES attending five institutions across the USA showed that the influence of self-efficacy plays an important role in attracting and retaining women in traditionally male-dominated career paths [4].

\subsection{WELA marketing and membership}

When WELA was established in 2011, a homeroom in the Engineering School on NMMU's campus was secured for WELA's activities. As a dedicated space for WELA members, the homeroom was significant for many reasons. It provided a space where members could find strength and support from one another, and experience a sense of belonging and fitting in. The homeroom created a feeling of cohesion and identity among the WELA members as a safe space for WES within a male-dominated environment. Owing to some of the WELA members' personal domestic situations, the WELA room also provided them with a quiet place to study and work. Finally, a dedicated venue provided credibility to WELA as a longterm project, and the branding of the venue reinforced and constantly reminded members of what WELA was and what it represented.

WELA was advertised and promoted within and outside NMMU. Many WES would have been exposed to WELA as high school learners and during faculty marketing events that promoted engineering courses at the university. WELA was widely advertised on NMMU's campus by various posters and marketing materials. Since 2012 a WELA video has also been used as a promotional tool; all of the first-year engineering students and their parents who attended the university's welcoming ceremony at the start of the academic year were shown the video. It provided details about WELA, including its aim and mission, and the numerous benefits of joining the association. Also featured in the video were WELA members representing the five engineering disciplines offered by the university. WELA members explained what their WELA membership meant to them and why a WES should consider joining WELA. During the first few weeks of the academic year, WES received WELA brochures and promotional materials, and were invited to attend the WELA launch. Since WELA's inception in 2011, the launches have taken place on a Friday afternoon at the 
beginning of March, once the students have completed their orientation, registered for their courses, and attended classes for at least two weeks. Even though it was preferable that WES join WELA as first-year students in order to gain maximum benefit from belonging to WELA, all levels of WES were welcome to join.

The aim of the annual launch was to provide an overview of WELA's co-curricular interventions and activities. At the launch, the various facilitators of the co-curricular interventions were invited to provide a brief overview of their respective interventions. In order to qualify as a WELA member, WES were required to attend a series of workshops presented by the university's Student Counselling Career Development Centre (SCCDC). Table 1 indicates how many WES have attended the launch since WELA's inception, how many have indicated that they would consider joining WELA, and how many WES have successfully completed the set of compulsory workshops to become fully-fledged WELA members.

Table 1: Overview of WELA's membership (2011-2014)

\begin{tabular}{|l|c|c|c|c|}
\hline & $\mathbf{2 0 1 1}$ & $\mathbf{2 0 1 2}$ & $\mathbf{2 0 1 3}$ & $\mathbf{2 0 1 4}$ \\
\hline WES who attended the launch & 27 & 46 & 87 & 116 \\
\hline WES who expressed interested in joining WELA & 14 & 35 & 83 & 72 \\
\hline $\begin{array}{l}\text { WES who attended the compulsory workshops in order } \\
\text { to qualify as a WELA member }\end{array}$ & 10 & 16 & 34 & 42 \\
\hline
\end{tabular}

From Table 1, it is evident that WELA membership has grown from 2011 to 2014, as membership has increased from ten new members in 2011 to 42 new members in 2014.

\subsection{WELA's leadership development programme}

WELA's leadership development programme (LDP), which was registered as an official university short-learning programme (SLP) in 2013, comprises a series of personal development workshops, academic and engineering-related interventions in the form of workshops, and SLPs aimed at work readiness and professional development. Lourens [2] and Lourens and Du Plooy [5] based the LDP design on several internal and external factors:

- Experience and knowledge gained from the 2011 and 2012 WELA programme of cocurricular interventions and development workshops;

- The values of the university, which include respect for diversity, excellence, 'ubuntu' (an African term roughly translated as human kindness), integrity, respect for the natural environment, and taking responsibility;

- The university's desired graduate profile, which includes in-depth disciplinary/ interdisciplinary knowledge, social awareness and responsible citizenship, adaptive expertise, creativity and innovation, critical thinking, and intra- and inter-personal communication skills [6];

- Input from professional practising female engineers and WES; and

- Input from various national and international women in other LDPs [7].

The need for WELA and their LDP was emphasised by the qualitative data gathered at the WELA launch events held from 2011 to 2014, using an open-ended questionnaire that required WES to provide the reasons why they chose to study towards an engineering qualification, who or what motivated them, what they expected to gain from joining WELA, and the challenges they foresaw working and studying in a traditionally male-dominated field. Respondents were not restricted in any way about how much detail they wished to provide when answering the open-ended questions.

Responses to the questionnaires over the four-year period indicated that WES's main anticipated obstacles as employees in a male-dominated workplace included: gender-based discrimination, a lack of collegial respect, sexism, being underestimated and seen as weak, not being taken seriously and not being able to cope with the engineering environment [ 2 , $5,8]$. The results were a clear indication that WES often had fears and insecurities about 
how they would be accepted, perceived, and respected in a traditionally male-dominated field of study or work [2].

Furthermore, in the period from 2011 to 2014, the top three reasons indicated by first-year WES for joining WELA were to gain skills that would ease the transitions from school to university and from university to the workplace, and to gain confidence and a sense of self [8]. Even if it could be argued that female engineers grew in confidence as they gained experience in the workplace, it was clear that the retention of WES needed to be actively pursued. It also became evident that there was a clear need for WES to be developed and prepared for continuing with their selected engineering courses, and to remain in the field of engineering.

This study argues that the development of the WELA LDP could assist WES not only to develop academically, professionally, and personally, but also to improve their sense of inclusion and their self-efficacy. As a result of joining WELA, members could gain confidence, which would in turn help them to overcome their insecurities and negative selfperceptions, and contribute to well-balanced, self-assured, and effective WES with a greater sense of inclusion. To test this claim, a longitudinal study was initiated in 2013. The study compared male and female students' self-efficacy scores at the beginning of the academic year. At the end of the year, all the students were tested again to establish whether the WELA LDP had influenced the self-efficacy scores of the WES who had joined WELA.

Findings from the longitudinal study will be published at the conclusion of the study in 2016. This article describes findings from various data sources gathered over a 42-month period, and discusses the influence of various WELA LDP co-curricular interventions on selfefficacy development. The next section presents the theoretical framework on which this study is based.

\section{THEORETICAL FRAMEWORK}

The WELA LDP was developed to incorporate the four sources of self-efficacy because of the benefits associated with increased self-efficacy [4], and because it was argued that increased self-efficacy could contribute to WELA achieving its goal of developing and retaining WES.

\subsection{Self-efficacy sources}

Self-efficacy is defined as a self-evaluation or self-belief of one's competence to execute successfully a course of action necessary to reach a desired outcome or goal [9]. It is a multi-dimensional construct that varies according to the domain of demands [10], and so it must be evaluated at a level that is specific to the outcome domain $[9,11]$. Thus, in academic settings, academic self-efficacy should be measured rather than generalised, as academic self-efficacy refers to students' belief in their ability to carry out academic tasks, such as preparing for and writing exams [12].

Furthermore, an extensive body of research has shown that academic self-efficacy is positively associated with grades at university [13-17], as well as with persistence [16, 18]. Bandura [3] posits that self-efficacy beliefs affect university outcomes by increasing students' motivation and persistence to master challenging academic tasks, and by fostering the efficient use of acquired knowledge and skills.

The four main sources of self-efficacy are:

\subsubsection{Mastery experiences}

A major source of self-efficacy is mastery experiences [3]. This denotes having the raw knowledge, skills, and experience required to complete a task or reach a goal. In the academic environment, a mastery experience implies a positive experience in completing a specific course. 


\subsubsection{Social persuasion}

As a source of self-efficacy, social persuasion refers to the influence of others. Hazari et al. [19] found that the presence or absence of social support influences course achievement. The women in the research study of Aluede et al. [20] identified social support as one of the strongest factors influencing their pursuit of studies in a technical field.

\subsubsection{Vicarious experiences}

Vicarious experiences occur when some form of involvement is experienced by observing someone else (a role model) engaged in a task [2]. The effect of a vicarious experience is dependent upon the similarity of the role model to the individual's own abilities and circumstances. Therefore the visibility of women and minorities in the engineering field is of paramount importance for WES.

\subsubsection{Physiological states}

Marra et al. [4] propose that the most compelling research on the impact of physiological states, and anxiety in particular, in WES is identified in the literature as 'stereotype threats'. This refers to the debilitating performance anxiety experienced by individuals who belong to a group for which there is a negative stereotype related to a task. For example, WES may experience debilitating anxiety in engineering-related careers and fields of study, owing to the stereotype or categorisation of these fields as being predominantly male. Research conducted by Li et al. [21] confirms that WES may show a higher level of anxiety than male counterparts, despite having better study competencies, motivation, and academic preparedness.

Cognisance was taken in the design of the WELA LDP of these four sources of self-efficacy, and the potential benefits associated with developing self-efficacy in an individual. The intention of the WELA LDP was not only to realise self-efficacy; it was also recognised that self-efficacy would be influenced as a product of implementing the WELA LDP.

\subsection{Promoting self-efficacy of WES through the WELA LDP}

The WELA LDP consisted of several co-curricular interventions that were aimed at the following broad categories: personal development, professional and work readiness, and academic and engineering-related topics. It was reasoned that development in these three broad categories could contribute to improved self-efficacy, thereby influencing the success and retention of WES $[2,4,12]$.

Table 2: WELA's LDP co-curricular interventions

\begin{tabular}{|l|l|c|l|}
\hline \multicolumn{1}{|c|}{ ALL ACTIVITIES } & \multicolumn{1}{c|}{ FORMAT } & GROUP* & \multicolumn{1}{c|}{ CATEGORY } \\
\hline Team building & Half-day workshop & J & Personal development \\
\hline Portfolio development & Half-day workshop & J & Personal development \\
\hline Wellness assessment & Half-day workshop & J & Personal development \\
\hline Strengths assessment & Half-day workshop & J & Personal development \\
\hline True Colours & Half-day workshop & J & Personal development \\
\hline Assertiveness & Half-day workshop & J & Personal development \\
\hline Conflict management & Half-day workshop & J & Personal development \\
\hline Self-leadership & Two-day workshop & S & Personal development \\
\hline Presentation skills & Half-day workshop & S & Professional \& work readiness \\
\hline Mentorship & One-day training & S & Professional \& work readinesS \\
\hline Publication & Year end & J & Professional \& work readiness \\
\hline Panel discussion & Half-day seminar & J \& S & Professional \& work readiness \\
\hline Exam preparation & Lunch-hour workshop & J \& S & Academic $\&$ engineering related \\
\hline Technical project & Year & S & Academic \& engineering related \\
\hline Proj ect management & Evening class $(24$ hrs) & S & Academic $\&$ engineering related \\
\hline Lean manufacturing & One-day workshop & S & Academic $\&$ engineering related \\
\hline
\end{tabular}

*Key: J = J unior WELA members (First year of WELA membership)

$S=$ Senior WELA members (WELA member for more than one year)

$\mathrm{J} \& \mathrm{~S}=\mathrm{J}$ unior and Senior WELA members

The elements of the WELA LDP are discussed in detail in the Sections 2.2.1 to 2.2.3. 
Difficulty was experienced in 2011 and 2012 when scheduling co-curricular interventions that would suit students across the five different engineering timetables. As a result, in 2013 Friday afternoons (from 12:00) were allocated to student projects and other interventions such as the WELA LDP. WELA workshops were also occasionally offered on Saturdays and during weekday lunchtimes. Table 2 illustrates the components of the WELA LDP, the format of the interventions that groups attended, and the type of intervention.

\subsubsection{Personal development co-curricular interventions}

Within the WELA LDP, various internal and external providers offered a series of personal development co-curricular interventions to WELA members.

\section{Personal development co-curricular interventions}

All aspiring WELA members were required to attend personal development workshops designed and presented by the NMMU's SCCDC.

For the WELA project, the decision was made to move away from a reactive and problemfocused approach to a more proactive personal-development approach that complied with the wellness approach [7, 23, 24]. The SCCDC's contribution to the WELA programme was thus from a personal development angle. Personal development can be described as a "lifelong journey of taking responsibility for oneself and moving forward, setting and achieving new goals, broadening one's life experiences, and moving closer to unfolding one's full aspirations" [23]. In light of this, four main co-curricular interventions were proposed:

- Introduction to the concept of wellness and holistic development group assessments, using the Wellness Questionnaire for Higher Education (WQHE);

- A strengths assessment;

- $\quad$ Feedback regarding the wellness and strengths assessments, and information on how to devise a plan of action to address areas that WES would like to develop further;

- Four group workshop sessions that focused on personal- and career-related issues: True Colours, Team-building exercises, Assertiveness and conflict management, and Portfolio development [23].

Upon successful completion of the SCCDC workshops, WES were qualified to become fullyfledged WELA members and allowed to attend the remainder of the WELA LDP.

\section{Self-leadership workshop}

In 2013, ten participants (who included senior WELA members and working female engineers) attended a self-leadership workshop. 'Self-leadership' was used as a comprehensive term for a variety of internalised personal development aspects/ strategies/ outcomes, including self-regulation and personal mastery. The main objective of the twoday leadership workshop, which was presented during the week-long September vacation, was to increase the self-efficacy of the participants [5]. The workshop addressed aspects of self-leadership, such as fear, stress, anxiety, gender, sex and identity, compassion, and happiness. Participants were also exposed to discussions on factors in the changing global workplace, building relationships, and the triad of success, leadership, and organisational dimensions.

The rationale for selecting these topics was based on identified problem areas that related to self-efficacy beliefs of women working/studying in male-dominated environments [3, 4, 25-28]. The intention of the workshop was to create (a) mastery experiences through the attaining of life skills, knowledge, and theories, as well as practice in meta-cognition; (b) positive social persuasion experiences through support and collaboration; (c) vicarious experiences through role modelling and role play; and (d) improved physiological states through motivation, encouragement, self-reflection, and analysis [5].

\subsubsection{Work readiness and professional development co-curricular interventions}

The work-readiness and professional development co-curricular interventions included:

Presentation skills 
From 2013, half-day workshops on presentation skills were offered on Friday afternoons to senior WELA members. Presentation skills often pose a challenge to students, many of whom have low levels of communication competence and high levels of apprehension. However, owing to the nature of the typical engineer's job, good presentation skills are important, since presenting proposals, projects, and results to an audience is often a core competency required of an engineer [30]. The ability to deliver a good presentation would therefore be an important skill to master, and Tucker and McCarthy [30] report a relationship between communication competencies, such as the ability to deliver a good presentation, and the supervisors' perceptions of overall subordinate job performance. Additionally, formal and informal oral or verbal communication is often an important competency required by employers [30].

\section{Mentorship}

Mentoring is defined as the process of guiding and facilitating less-experienced students to achieve growth and reach their potential [31]. A senior academic development professional from NMMU trained senior WELA members who were interested in mentoring junior WELA members for one full day on a Saturday. In particular, the senior WELA members were trained to support their mentees in the following ways:

- Academic and personal development;

- Adj ustment and coping support;

- $\quad$ Life skills development;

- Role modelling; and

- Emotional and psychological support.

WELA mentorship was thus about helping junior WELA members in a friendly, supportive, caring, and structured relationship that focused on the needs of the mentored student, and was based on encouragement, constructive comments, openness, mutual trust, respect, and a willingness to share and learn [31].

\section{Publications}

As argued by Marra et al. [4], the visibility of women and minorities in the field of engineering is of paramount importance for women and minorities in order to influence their self-efficacy beliefs positively. A female role model is particularly influential in areas where there are negative gender stereotypes. In addition, women who reported being influenced by positive role models had higher career aspirations in engineering fields [ 28 , 32]. It was found that female role models who demonstrated success in the engineering field contributed to other female engineers' feelings of belonging [33].

As a result, since 2011 the WELA project team has issued an annual publication called Inspirational Women, which features ten successful women working in the engineering field in the Eastern Cape Province in South Africa. Secondly, an Inspirational Students booklet has been published, featuring first-year WELA members. Professional photographs were also taken of the WELA members, and each member wrote a self-reflection article on what it meant to be a part of WELA, of the engineering world, and of what they had learnt and gained during their first year as junior WELA members.

\section{Panel discussion}

Darby [41] proposed that women, to a greater degree than men, considered supportive persons, including role models, as important. Zeldin and Pajares [27] found that women valued persuasion (direct encouragement) and vicarious experiences (seeing a person similar to oneself succeeding), as opposed to men who valued mastery experiences as critical to their self-efficacy beliefs [42]. As a result, a panel discussion was hosted annually on a Friday afternoon, and women and men from different industries were invited to discuss topics such as "The road to success - a female perspective", "The engineer and globalisation", and "How engineers can do good". The panel discussions were open to junior and senior WELA members. 


\subsubsection{Academic and engineering-related co-curricular interventions}

In partnership with two academic engineering departments, namely Industrial and Mechanical Engineering, engineering-related co-curricular interventions to prepare and empower WELA members for the world of work were offered. Since 2012 WELA members have attended SLPs in 'Lean Manufacturing' and 'Project Management', taken part in a technical project, and attended study skills workshops to prepare themselves for upcoming examinations.

\section{'Lean Manufacturing' and 'Project Management' SLPs}

The engineering-related workshops presented to senior WELA members by the Department of Industrial Engineering comprised a two-day 'Lean Manufacturing' SLP and a four-day 'Project Management' SLP. Exposure and training in lean manufacturing knowledge seemed an important choice, owing to the applicability and prevalence of the lean philosophy in the automotive sector, where the majority of the university's engineering students were employed or had completed their in-service training. Furthermore, lean manufacturing formed part of the curriculum of only one of the engineering courses, and so a limited number of the senior WELA members had any lean manufacturing knowledge.

The other SLP offered to senior WELA members was 'Project Management'. Although the topic of this SLP was explored in some undergraduate engineering courses, the majority of the engineering courses did not offer project management as part of their curriculum. This SLP covered all aspects, from project initiation to closing the project and best practices.

\section{Technical project}

Since 2012 senior WELA members have participated in a technical project. In 2012, WELA members designed a water harvesting system; in 2013 and 2014, senior WELA members were involved with designing and building a portable study table for wheelchair users at the university. The technical project was organised and managed by the senior WELA members, together with a senior academic staff member who acted as mentor and coach.

\section{Examination preparation}

In an effort to reduce stress and anxiety and to provide moral support, all WELA members were issued with examination survival packs to assist them while preparing for and writing exams. The packs consisted of examination study tips, stationery, and healthy food snacks and beverages. During 2012, this intervention was taken a step further by incorporating a workshop on study skills to help WELA members have the positive experience of completing a specific engineering course.

By means of feedback and evaluation forms, data was gathered from WELA members who attended these co-curricular interventions. The data was collected and interpreted against the theoretical framework discussed in this section. The research design is discussed in the next section.

\section{RESEARCH DESIGN}

The research design of this study is based on a phenomenological approach. According to Lester [22], the "purpose of the phenomenological approach is to illuminate the specific, [and] to identify phenomena through how they are perceived by the actors in a situation". This paper reports on the qualitative, descriptive, and interpretive study of the possible influence of elements of the WELA LDP on the sources of self-efficacy.

This research critically analyses and describes findings from qualitative data gathered from the inception of WELA in 2011 to J une 2014. The participants in this study were WELA project team members and WES belonging to WELA. Data sources used in this study included various evaluation and feedback forms that were completed by WELA members, and reflective narratives written by junior WELA members at the end of their first year as a WELA member. Table 3 illustrates the WELA LDP categories, a condensed summary of the WELA LDP interventions, the instrument used to obtain data from the respective WELA LDP 
categories, the main data types extracted from each category, and the reason why the data was extracted.

Table 3: Research design

\begin{tabular}{|c|c|c|c|c|}
\hline $\begin{array}{l}\text { Category/ } \\
\text { Activity }\end{array}$ & $\begin{array}{l}\text { Design dimension and } \\
\text { intended outcome }\end{array}$ & Instrument & $\begin{array}{l}\text { Main data } \\
\text { extracted }\end{array}$ & Reason \\
\hline $\begin{array}{l}\text { Personal } \\
\text { development } \\
\text { workshops }\end{array}$ & 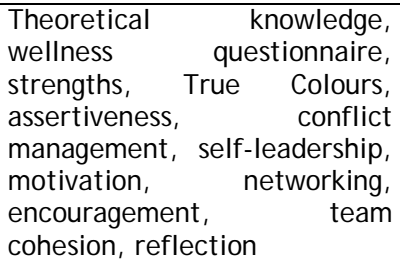 & $\begin{array}{l}\text { Open-ended } \\
\text { questionnaire }\end{array}$ & $\begin{array}{l}\text { Respondent's } \\
\text { reflections }\end{array}$ & $\begin{array}{l}\text { To } \\
\text { determine } \\
\text { the } \\
\text { influence on } \\
\text { the sources } \\
\text { of self- } \\
\text { efficacy }\end{array}$ \\
\hline $\begin{array}{l}\text { Professional } \\
\text { development } \\
\text { and work } \\
\text { readiness co- } \\
\text { curricular } \\
\text { interventions }\end{array}$ & $\begin{array}{l}\text { Theoretical knowledge and } \\
\text { practical application, } \\
\text { presentation skills, } \\
\text { mentorship, social support, } \\
\text { role models, motivation, } \\
\text { encouragement, reflection }\end{array}$ & $\begin{array}{l}\text { Open-ended } \\
\text { questionnaire }\end{array}$ & $\begin{array}{l}\text { Respondent's } \\
\text { reflections }\end{array}$ & $\begin{array}{l}\text { To } \\
\text { determine } \\
\text { the } \\
\text { influence on } \\
\text { the sources } \\
\text { of self- } \\
\text { efficacy }\end{array}$ \\
\hline $\begin{array}{l}\text { Academic and } \\
\text { engineering- } \\
\text { related co- } \\
\text { curricular } \\
\text { interventions }\end{array}$ & $\begin{array}{lr}\text { Theoretical } & \text { knowledge, } \\
\text { practical application } \\
\text { engineering principles, lean } \\
\text { manufacturing and project } \\
\text { management, } \\
\text { preparation, texam } \\
\text { leadership skills, mastery, } \\
\text { social support, improved } \\
\text { physiological states, } \\
\text { motivation and } \\
\text { encouragement, reflection }\end{array}$ & $\begin{array}{l}\text { Open-ended } \\
\text { questionnaire }\end{array}$ & $\begin{array}{l}\text { Respondent's } \\
\text { reflections }\end{array}$ & $\begin{array}{l}\text { To } \\
\text { determine } \\
\text { the } \\
\text { influence on } \\
\text { the sources } \\
\text { of self- } \\
\text { efficacy }\end{array}$ \\
\hline
\end{tabular}

The researcher reviewed the source documents to extract themes, which were then discussed with the project team. The emergent themes informed the key issues in the discussion section and highlighted the influence of various elements of the WELA LDP on the four sources of self-efficacy. To validate the findings, two members of the project team were invited to review the findings, and their feedback and comments were incorporated.

The data revealed that a range of interventions had been implemented successfully and had contributed to improved self-efficacy in WES. The following sections reflect on key aspects of the WELA LDP and on the influence of the various co-curricular interventions on the four sources of self-efficacy.

\section{FINDINGS AND DISCUSSION}

The WELA LDP discussed in this article was aimed at developing WES on a personal, professional, and academic level. The co-curricular interventions were categorised as being developmental, professional, academic, or engineering-related. The sections below discuss the components of the WELA LDP in more detail.

\subsection{Personal development co-curricular interventions}

SCCDC's co-curricular interventions and self-leadership workshops were designed as personal development co-curricular interventions. The potential impacts of these cocurricular interventions on the sources of self-efficacy are discussed below.

\subsubsection{SCCDC's co-curricular interventions}

The WELA LDP began with a series of developmental co-curricular interventions presented by SCCDC staff. At the end of every year, WELA participants were asked to rate SCCDC's Cocurricular interventions and to write a short narrative on what attending the workshops meant to them. The majority of the responses rated the co-curricular interventions as 
'good' or 'very good', and the responses highlighted how participants found value in these interventions.

When evaluating SCCDC's co-curricular interventions in terms of self-efficacy sources, it can be argued that WELA members mastered new skills such as conflict management and assertiveness (mastery experiences). In addition, WELA members learnt more about themselves as individuals. The workshops created an environment for WELA members to make connections with other WES in the engineering faculty, which led to WELA members forming a cohesive team (social persuasion). WELA members supported one another strongly, not only academically, but also emotionally and socially. Most of the respondents remarked that they felt more confident because they had gained greater self-knowledge, identified their weaknesses, and built on their strengths (improved physiological states). A final important finding was that the majority of participants stated that the workshops prepared them for coping in the workplace.

\subsubsection{Self-leadership workshop}

Feedback data, which was collected by means of open-ended questionnaires that were completed by the self-leadership workshop's participants, indicated that they had valued the workshop. The workshop, which was attended by WELA members and professional female engineers, had created networking opportunities and exposed the participants to new perspectives and ways of thinking. The workshop also created mastery experiences through the attaining of life skills, knowledge, and theories. It promoted positive social persuasion experiences through support and collaboration, vicarious experiences through role modelling and role play, and improved physiological states through motivation, encouragement, self-reflection, and analysis. Participants also enjoyed learning that they were not alone and that other women faced similar experiences. The workshop created the opportunity for self-reflection and self-development [29].

\subsection{Professional and work readiness co-curricular interventions}

A presentation skills workshop, mentorship training, publications, and panel discussions were designed to develop WELA members professionally, and to prepare them for the world of work. The potential impacts of these co-curricular interventions on the sources of selfefficacy are discussed below.

\subsubsection{Presentation skills workshop}

Because engineering students were required to deliver presentations during the course of their engineering studies, WELA members attended a presentation skills workshop where they received in-depth feedback from peers and facilitators. Nine WELA members attended this workshop in 2013, and 11 attended in 2014. Participation in and successful completion of the workshop reduced possible apprehension about delivering presentations (improved physiological states), allowed members to build confidence in a supportive environment (social persuasion), and helped members to master the skill of delivering a good presentation among peers with similar backgrounds and abilities.

\subsubsection{Mentorship}

The number of WELA members who were trained as mentors increased from eight in 2012 to 16 and 26 members in 2013 and 2014 respectively. They usually mentored not more than three junior WELA members, who preferably studied the same engineering course as the mentor. Mentors and mentees were encouraged to meet at least twice a month, and both the mentor and mentee were required to keep a meeting diary that was then filed in their individual personal portfolios. For senior WELA members, the mentoring programme was an opportunity to provide motivation, encouragement, and social support, in addition to acting as role models for junior WELA members. This was especially helpful if the mentor and mentee had similar backgrounds. Being trained and acting as a mentor allowed senior WELA members to improve their communication, planning, leadership, and interpersonal skills. This was confirmed by data gathered from open-ended feedback forms in which respondents stated that they gained an understanding of the importance of their role as mentors, in addition to gaining leadership skills, improved communication skills, and confidence. Furthermore, being a mentor allowed senior WELA members to recognise their 
own skills and worth, develop their facilitation competencies, and enhance their sense of self-development and self-knowledge.

For the mentees, the mentorship programme increased their social and academic integration, especially since the mentor was a person of the same gender who was studying within the same environment. Thus they had direct access to positive role models in addition to developing certain skills, competencies, and knowledge. For both the mentor and mentee, this co-curricular intervention was valuable for enhancing mastery experiences, social persuasion, vicarious experiences, and physiological states.

\subsubsection{Publications}

In their written reflections, the women featured in the Inspirational Women publication described a typical workday, and the challenges associated with their jobs and with being a woman in a male-dominated environment [35-37]. They also gave advice to other women entering a male-dominated career environment. This publication served as an inspiration to the WELA members and other women working in the field. It also showed that most women face and overcome the same challenges and fears [34]. This supports the argument by Richman and van Dellen [33] that successful female engineers developed a means of coping with social identity threats that arose from being a minority in the field.

Narratives written by first-year WELA members for the Inspirational Students publication indicated that they valued the WELA LDP as a means to personal and professional growth and development, thereby improving their confidence and leadership skills. Furthermore, WELA was valuable in building support systems and assisting WELA members with adjusting to university life and engineering studies. The self-reflection articles written by WELA members were indicative of the positive influence that the WELA LDP had on the participants' self-efficacy [38-40].

\subsubsection{Panel discussions}

The visibility of women and minorities were of paramount importance to ensure vicarious experiences where the participants could see women of similar abilities and circumstances achieving success in the workplace. Feedback data collected after each panel discussion (2011-2014) indicated that the majority of the students could relate equally to both the male and female speakers. Although the respondents were more motivated by the female speakers than by the male speakers, they indicated that they would like to hear again from both genders [34]. The value of the panel discussion came from the interaction of the WELA members as aspiring engineers, with women working in the field. Apart from motivating and assuring the WELA members that they could be successful in a male-dominated environment, the panel members shared their personal experiences of work insecurity.

\subsection{Academic and engineering-related co-curricular interventions}

Two SLPS and an examination preparation workshop were designed to support WELA members academically. The potential impacts of these co-curricular interventions on the sources of self-efficacy are discussed below.

\subsubsection{SLPs}

For many of the senior WELA members, the 'Lean Manufacturing' and 'Project Management' SLPs were their first exposure to learning and training in a subject area other than engineering.

Senior WELA members attended the 'Lean Manufacturing' SLP to prepare them for lean terminology and philosophies that they would encounter when they entered the workplace. In 2012, eight WELA members attended this SLP, and in 2013 and 2014, there were 10 and 16 WELA members in attendance, respectively. Attending the 'Lean Manufacturing' SLP empowered the WELA members and gave them confidence, as they were more interviewand work-ready after having had exposure to some of the basic concepts of lean manufacturing. 
By attending the 'Project Management' SLP, senior WELA members with limited project management experience gained a better understanding of project management, and learned new techniques to improve their effectiveness in managing projects. WELA members involved with the technical project specifically requested this workshop, as it would assist them greatly in planning, managing, and executing their technical project brief. Two WELA members attended the 'Project Management' SLP in 2012, 19 attended in 2013, and 14 attended in 2014.

The SLPs taught skills that WELA members could apply in their personal and work life. Attending the SLPs provided them with lean manufacturing and project management knowledge and skills (mastery experiences) that would set them apart from those who had not attended such SLPS, thereby empowering them and building their self-confidence.

\subsubsection{Technical project}

In 2012, five WELA members designed a water harvesting system. In 2013 and 2014, 13 senior WELA members were involved with designing and building a portable study table for wheelchair users at the university. Participation in technical projects has allowed the senior WELA members to practise their individual engineering specific skills, in addition to the lean manufacturing, project management, and teamwork and presentation skills that they had acquired. Several WELA members rated the technical project as a highlight of the WELA LDP. The technical project allowed WES the opportunity to work with students from other engineering disciplines [40], and it created the opportunity for a simulated work experience, as the students had to conceptualise and present a design, manage meetings, plan and execute work, and work in a team.

\subsubsection{Examination preparation workshop}

Since 2012, WELA members have attended a workshop on study skills to assist them in preparing for examinations. Attending the workshop could contribute to positive examination results, which would lead to WELA members successfully completing their respective academic courses, thus influencing mastery experiences and physiological states. In 2012, 23 WELA members attended the workshop; in 2013, 46 attended.

\section{CONCLUSION}

The study's findings and discussion revealed that co-curricular interventions could be developed and incorporated into a formal engineering curriculum. The combination of selfdevelopment courses, work preparation, and engineering-related workshops could improve self-efficacy among WES, which could lead to a greater retention of WES and professional working female engineers.

This research indicated how co-curricular interventions could influence WES's sense of selfefficacy. The results of this research could contribute to the current body of knowledge on retention of women in engineering. This research could therefore support the development of additional co-curricular interventions that could improve the retention rate of women studying and working in the field of engineering.

The process and co-curricular interventions described in this research provide a platform for further research and development, especially in the field of women in engineering in the South African context. As a result, the researcher has also embarked on a longitudinal study to measure the sources of self-efficacy before and after WELA's interventions, for WES attending NMMU. This study could also be replicated at other South African universities by incorporating similar WELA programme interventions that aim to improve the attraction, education, retention, and success of women in the engineering, science, and technology fields. Furthermore, future research could indicate possible improvements to enhance and expand the WELA LDP. 


\section{REFERENCES}

[1] Du Toit, R. \& Roodt, J. 2009. Engineers in a developing country - The profession and education of engineering professionals in South Africa. Cape Town: HSRC Press.

[2] Lourens, A.S. 2013. The design of a leadership development programme for women engineering students at a South African University. American Society for Engineering education, Annual Conference. 23-26 J une, Atlanta Georgia.

[3] Bandura, A. 1997. Self-efficacy: the exercise of control. New York: W.H. Freeman and Company.

[4] Marra, R. M., Rodgers, K.A., Shen, D. \& Bogue, B. 2009. Women engineering students and selfefficacy: A multi-year, multi-institution study of women engineering student self-efficacy. J ournal of Engineering Education, 98(1), pp. 27-38.

[5] Lourens, A.S \& Du Plooy, B. 2014. A South African perspective on self-leadership development for women engineering students - A pilot study. International Conference on Women in Science, Engineering and Technology (WASET). 12-13 March, Dubai UAE.

[6] NMMU. 2013. Nelson Mandela Metropolitan University. Retrieved from www. vision2020.nmmu. ac. za. Accessed on 21 August 2013.

[7] Graham, R., Crawley, E. \& Mendelsohn, B.R. 2009. Engineering leadership education: A snapshot of international good practice. White paper sponsored by the Bernard M. Gordon-MIT Engineering leadership program.

[8] Lourens, A.S. 2014. Informal survey of first year WES. Port Elizabeth, South Africa: Nelson Mandela Metropolitan University.

[9] Bandura, A. 1986. Social foundations of thought and action: A social cognitive theory. Englewood Cliffs, NJ : Prentice-Hall.

[10] Zimmerman, B.J. 2000. Self-efficacy: An essential motive to learn. Contemporary Educational Psychology, 25, pp. 82-91.

[11] Pajares, F. 1996. Self-efficacy beliefs in academic settings. Review of Educational Research, 66(4), pp. 543-578.

[12] Lourens, A.S. \& Pannell, L.S. 2013. Self-efficacy of engineering students at NMMU. Report 1. Port Elizabeth, South Africa.

[13] Bong, M. 2001. Role of self-efficacy and task-value in predicting college students' course performance and future enrolment intentions. Contemporary Educational Psychology, 26(4), pp. 553-570.

[14] Brown, S.D., Lent, R.W. \& Larkin, K.C. 1989. Self-efficacy as a moderator of scholastic aptitude: Academic performance relationships. J ournal of Vocational Behavior, 35(1), pp. 64-75.

[15] Hackett, G., Betz, N.E., Casas, J.M. \& Rocha-Singh, I.A. 1992. Gender, ethnicity, and social cognitive factors predicting the academic achievement of students in engineering. Journal of Counseling Psychology, 39(4), pp. 527-538.

[16] Lent, R.W., Brown, S.D. \& Larkin, K.C. 1984. Relation of self-efficacy expectations to academic achievement and persistence. J ournal of Counseling Psychology, 31(3), pp. 356-362.

[17] Multon, K.D., Brown, S.D. \& Lent, R.W. 1991. Relation of self-efficacy beliefs to academic outcomes: A meta-analytic investigation. J ournal of Counseling Psychology, 38, pp. 30-38.

[18] Zhang, Z. \& Richard, R.S. 1998. Prediction and analysis of freshman retention. Paper presented at the Annual Forum of the Association for Institutional Research. Minneapolis, MN.

[19] Hazari, Z., Tai, R.H. \& Sandler, P.M. 2007. Gender differences in introductory university physics performance: The influence of high school physics preparation and effective factors. J ournal of Science Education, 91(6), pp. 847-876.

[20] Aluede, 0.0., Imahe, C.I. \& Imahe, J. 2002. University female students' motives in enrolling for non-traditional degrees. Australian J ournal of Career Development, 11(2), pp. 45-48.

[21] Li, Q., Swaminathan, H. \& Tang, J . 2009. Development of a classification system for engineering student characteristics affecting college enrolment and retention. Journal of Engineering Education, 98(4), pp. 361- 376.

[22] Lester, S. 1999. An introduction to phenomenological research. Taunton, UK: Stan Lester Developments. Retrieved from www.sld.demon.co.uk/ resmethy.pdf. Accessed on 18 September 2014.

[23] Ramasamy, K. 2011. Student counselling, career, and development centre (SCCDC). Report on SCCDC'S contribution to the women in engineering leadership association (WELA) project in 2011. Port Elizabeth, South Africa: Nelson Mandela Metropolitan University.

[24] Van Lingen, J.M. 2000. Proposal for a UPE wellness plan. Port Elizabeth, South Africa: University of Port Elizabeth.

[25] Brainard, S. \& Carlin, L. 1998. A six-year longitudinal study of undergraduate women in engineering and science. J ournal of Engineering Education, 87(4), pp. 369-375.

[26] J ackson, L.A., Gardner, P.D. \& Sullivan, L.A. 1993. Engineering persistence: Past, present and future factors and gender differences. Higher Education, 26, pp. 227-246.

[27] Zeldin, A. \& Pajares, F. 2000. Against the odds: Self-efficacy beliefs of women in mathematical, scientific and technical careers. American Educational Research J ournal, 37(1), pp. 215-246. 
[28] Li, Q., Swaminathan, H. \& Tang, J. 2009. Development of a classified system for engineering student characteristics affecting college enrolment and retention. Journal of Engineering Education, 98, pp. 361-376.

[29] Lourens, A.S. \& Du Plooy, B. 2014. Addressing low self-efficacy in South African women engineering students: Evaluation of a university-based pilot project. Unpublished article.

[30] Tucker, M. L. \& McCarthy, A.M. 2011. Presentation self-efficacy: Increasing communication skills through service learning. J ournal of Managerial Issues, 13(2), pp. 227-244.

[31] Plaatjies, R. 2011. Mentoring at the NMMU. Report by the Centre for Teaching and Learning and Media (CTLM). Port Elizabeth, South Africa: Nelson Mandela Metropolitan University.

[32] Nauta, M.M., Epperson, D.L. \& Kahn, J.H. 1998. A multiple group analysis of predictors of higher-level career aspirations among women in mathematics, science and engineering majors. J ournal of Counseling Psychology, 45, pp. 483-496.

[33] Richman, L.S. \& Van Dellen, M. 2011. How women cope: Being a numerical minority in a male dominated profession. Journal of Social Issues, 67(3), pp. 492-509.

[34] Lourens, A.S. 2014. Engineering co-curricular role model interventions to develop women engineering students' self-efficacy at a South African university. The International Academic Forum, European Conference on Education. July 9-13, Brighton, UK.

[35] WELA. 2011. Inspirational Women: $1^{\text {st }}$ edition. WELA Publication: Nelson Mandela Metropolitan University.

[36] WELA. 2012. Inspirational Women: $2^{\text {nd }}$ edition. WELA Publication: Nelson Mandela Metropolitan University.

[37] WELA. 2013. Inspirational Women: $3^{\text {rd }}$ edition. WELA Publication: Nelson Mandela Metropolitan University.

[38] WELA. 2011. Inspirational Students: $1^{\text {st }}$ edition. WELA Publication: Nelson Mandela Metropolitan University.

[39] WELA. 2012. Inspirational Students: $2^{\text {nd }}$ edition. WELA Publication: Nelson Mandela Metropolitan University.

[40] WELA. 2013. Inspirational Students: $3^{\text {rd }}$ edition. WELA Publication: Nelson Mandela Metropolitan University.

[41] Darby, J.L. 1992. Undergraduate engineering: Some problems faced by women students. Issues of Human Diversity in Water Resources, 89, pp. 3-7.

[42] Marx, D.M. \& Roman, J.S. 2002. Female role models: Protecting women's math test performance. Personality and Social Psychology Bulletin, 28, pp. 1183-1193. 